\title{
Henads as Divine Images: The Epistemological and Ontological Significance of Inner Light and Creation of a New Subjectivity in Ioane Petritsi's Metaphysics
}

\author{
Levan Gigineishvili \\ Ilia State University, Tbilisi
}

In the present article I shall deal with the ontological and epistemological significance of light in Ioane Petritsi's philosophy. I will deal with the issue of the hierarchy of metaphysical entities that can be also expressed as a system of light-bestowals starting from the Highest Principle - the One, down to the extremity of material reality. The system is basically grounded upon the Neoplatonic metaphysical pattern as presented in the greatest 'systematizer' of this tradition, Proclus. However, as a Christian, Petritsi finds himself in a position of duty to reshape the Proclian system quite drastically in order to accommodate it to some basic Christian tenets. Most important with this respect is the increased distance between God, whose nature Petritsi views in Trinitarian terms, and the metaphysical entities that come down from it. To be precise, Petritsi constructs a totally different and idiosyncratic theory of Proclian divine entities - the henads: on the one hand, lessening their status, because they can no longer be the 'gods' properly speaking, and on the other hand, humanizing them, making them the very centers of human personalities. An indwelling henad appears to be the same as the inner logos, the inner principle of cognition that is present in every human being qua human being. Now, exactly this inner principle, the inner light, is not self-sufficient and even self-creating in the strong Proclian sense, but itself in need of illumination from the divine Logos, who is called by Petritsi the "Light of philosophers". The problem arises as to the ontological status of the inner logos, or if my identification is correct, the indwelling henad: is it an irremovable part of the human being, coming to existence together with him/her? Or is it an immanent presence of a divine illumination that is not irremovable and indivisible from a human personality, but on the contrary, in principle, removable from the human being? Is it conscience? But what is then conscience? What is its metaphysical status after all? Is it different in every person and thus uniquely individualized, or is it a general

(C) KONINKLIJKE BRILL NV, LEIDEN, THE NETHERLANDS, 2022 | DOI:10.1163/9789004501331_008 
illumination for all humans qua humans? These are lofty questions, to which Petritsi does not dedicate a special treatise, but rather tackles while discussing various metaphysical-theological issues. We now engage in a difficult task of extracting the philosopher's explicit teachings on these issues.

In the following, I shall attempt to prove that Petritsi integrates henads within each human personality, making the henads principles of the uniqueness of each person. I will demonstrate that henads represent inner lights through which humans ascend and participate in the divine Logos. By conceiving these unique personal lights as the centers of each human being, Petritsi seems to have created a novel vision of a human subject that allows for its shift towards a greater degree of autonomy, self-sufficiency and independence and hence also a greater degree and novel dimension of personal responsibility.

In fact, the issue of the relation of human intellectual-cognitive capacity with the divine is a mystery that is not readily explained in the New Testament. In Pauline theology Christians possess the "Mind of Christ", but there is no further reflection on what is that in us which receives the Mind of Christ. Further, we read about human conscience rooted in the Holy Spirit, which suggests a certain interaction and reciprocity. However, the discourse in Romans 9:1 does not go deeper to clarify this interrelation and reciprocity. It is tempting to interpret Petritsi's henadic doctrine in the light of traditional Eastern Orthodox theology, à la Cappadocians, as has been done by Magda Mchedlidze in her article on the cognitive criterion in Petritsi: ${ }^{1}$ the Cappadocians utilize the Stoic concept of "the ruling part" ( $\tau \dot{0}$ í $\gamma \varepsilon \mu o v i x o$ v) in us, which according to Gregory Nazianzus comes in a direct, albeit, blurred and partial, touch with the Godhead, and is thus divinized. ${ }^{2}$ However, the Cappadocians do not use a technical metaphysical language and do not create clear theoretical-metaphysical schemes as does Petritsi through the influence of Proclus' systematizing genius. Petritsi, through the influence of Proclus and "rubbing", as it were, the Biblical and Neoplatonic traditions, constructs a rigid metaphysical-epistemological theory of relationship of the human cognitive light with the divine light. By this, as indicated above, he constructs a novel understanding of human per-

1 Mchedlidze 2013, p. 355-362.

2 Cf. Gregory Nazianzen, Oratio 38 ("On the Theophany or Birthday of Christ"), ch. 7 (PG 36.

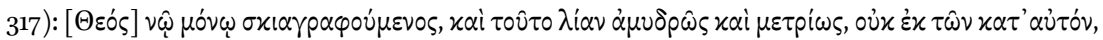

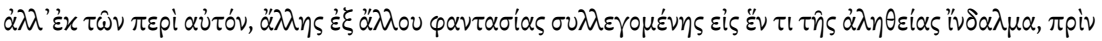

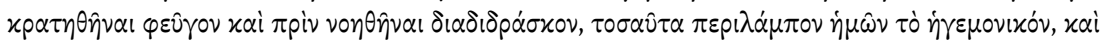

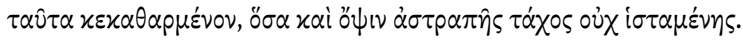

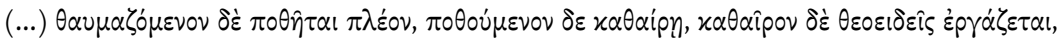

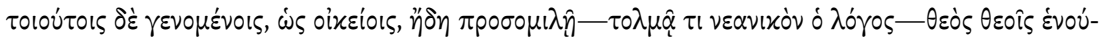

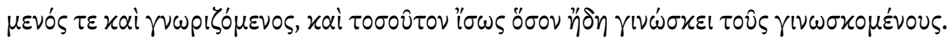


sonality, a new dimension of self and self-engagement. To be precise, the status of the self and its independent cognitive activity is radically accentuated so as to eclipse the importance of the tradition of the Church which used to form a kind of a holy trustworthy inertia carrying along its current the mind and convictions of a believer. The tradition, thus, could be viewed as an interpretative light, a criterion coming from the "holy outside". Contrary to this, for Petritsi the balance for the criterion of truth shifts towards a person's free cognition in the inner motion of the intellectual soul and away from a faithful adherence to something external and outward; that is to say, the light is not to be accepted from outside by any leap of faith or pious awe and obedience, but to be found inside and kindled from within a person him/herself.

The inner light, the inner principle of cognition in Petritsi is emphasized and valorized so as to eclipse the importance of the holy tradition. More dramatically, if the two, that is to say, the inner cognition and tradition would collide, Petritsi would choose to adhere to and support the former as something truly holy. In this light, eventually, I will mention the issue of Church authority: the tradition still retains its importance for Petritsi, but it should be based already on estimation from the part of the inner light, the inner logos, itself illumined directly by or participating in the divine Logos, the "Light of the Philosophers". I suggest that this new attitude and shift towards inwardness in a cognitive ascent towards the divine must have been the basic reason for Petritsi's persecution from the official clerical circles in Byzantium and Georgia, which the philosopher bitterly laments.

\section{$1 \quad$ Christianized Henads}

Henads in Proclus are gods properly speaking and deserve devotional prayers. They are self-creating ( $\alpha \dot{\theta} \theta u \pi \delta ́ \sigma \tau \alpha \tau \circ \varsigma)$ entities and function as revelators of a hidden richness in the One, accounting for the One's presence in the multiplicity of beings in a manner peculiar to each being. The differences between beings are grounded on henadic differences, which in their supra-essential realm remain totally indiscernible to our mind but get revealed in beings. The human mind can systematize and build a hierarchy of them only secondarily, through their manifestations in beings. Thus, paradoxically, henads are in a sense rays of the One that cannot be differentiated in themselves, but beings that participate in them "force", as it were, them to reveal their latent differences. Henads in Proclus, by comparison with the imparticipable One, let or allow beings to participate in themselves and through this participation in fact 
create them. However, henads do not participate in anything higher, not even in the One. Now, in Petritsi's metaphysics, henads are the "lights" of the One, like the very rays of the One. As it is with Proclus, they also function as participable entities that are differentiated in beings and are responsible for the plurality of different genera and species. However, there is a crucial difference in respect to Proclus: for Petritsi the henads are not gods per-se-although Petritsi does call them sometimes "gods" — but they are referred to rather as "divine in virtue of participation", or "divinized / deified" through participation. Once he calls henads "deified gods", and even uses a biblical wording with reference to them as "supra-substantial images of God". Thus, in a drastic difference from Proclus, Petritsi makes henads participants of something higher than themselves and, as such, they have a divine status only derivatively as partakers of the divine proper. What is this higher? It cannot be immediately the imparticipable One due to His very imparticipability. But henads participate in the metaphysical principle of the Limit, which is referred to as the "second One" and a participable Monad of the series of henads. To demonstrate that, let us consider Petritsi's commentary on prop. 116 of the Elements:

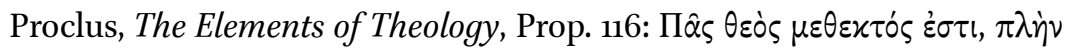

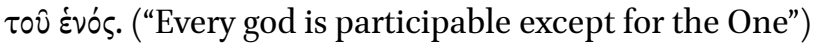

Petritsi's translation: "Every god-by-virtue-of-participation participates in ${ }^{3}$ [something above it] except for the One."

Petritsi's commentary:

The causes of the ones (i.e. henads) are to be distinguished: in fact, there is the First Cause of the ones, yet He does not give His properties to the subsequent ones (henads). However the [second] One produced by Him is already a Cause that distributes His properties within the series of the ones [henads]. Thus, the first One is beyond and transcendentally abstracted from all the ones and not to be established in the series of the ones, being the Unique One, whereas the One that is produced by Him, is

3 Petritsi here changes the wording and meaning of Proclus' text, producing a different metaphysical theory: instead of $\theta$ cós he writes "god-in-virtue-of participation", that is to say, something that is made god or divinized through participation, and then instead of "participable" puts "participates in [something higher]", thus relativizing the Proclian gods into entities that participate in something higher-the One which is God in the proper sense-and are thus divinized. 
the Head and Origin of the series of the ones; and this [second One] is not unified, for the unified one [i.e. the First Intellect], is other and the One begotten from the transcendent One is the other, for the begotten One is above all series as the Head of the series and the Head of the ones. ${ }^{4}$

The same is repeated elsewhere:

Before producing the multiplicity, the One first produces the [second] One (i.e. the Son/Logos) and the series of the henads follow after that. ${ }^{5}$

This Limit is explicitly identified by Petritsi with the Trinitarian Hypostasis of the Son ${ }^{6}$ and Infinity with the Trinitarian Hypostasis of the Holy Spirit. The One, the Limit and Infinity represent the Godhead proper, whereas the henads are referred to as "created". Thus, unlike Proclus, Petritsi puts a gap in the highest metaphysical level between the Trinitarian Godhead and created entities - henads, which are now deified only through participation in the $\pi \dot{p}$ pas-Logos.

The henadic ranks, as said above, account for the ranks and hierarchy in the entire universe, and in fact henads play a crucial role in the process of ascent of the beings to their source- the One:

When the effect participates in its cause first it participates in its own henad, through this henad it participates in higher henads and causes, and so on, and from henad to henad it returns to the One that is above the henads. ${ }^{7}$

Now in Proclus, there are different ranks of the proper henad-gods, however there are also within each henadic rank some offshoots of lights from the henads-proper, which offshoots are not already henads properly speaking but their "illuminations" ( $(2 \lambda \alpha \mu \mu \psi(\varsigma)$ or "echoes" ( $\dot{\alpha} \pi \dot{\eta} \chi \eta \mu \alpha)$. Petritsi also adheres to this doctrine of the lesser lights, however with a principal difference with regard to the human soul: in Proclus' account the human soul's unifying prin-

4 Ioane Petritsi, Commentaria, vol. II, p. 157-158. Henceforth I will refer to this book as Commentaries, and the final part of it, which deals with the Book of Psalms, as Epilogue.

5 Ioane Petritsi, Commentaria, vol. II, p. 78.

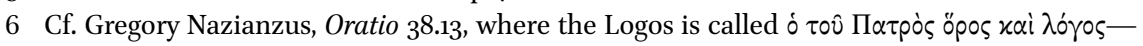
the limit; however, Petritsi is more directly influenced by Proclus, for he translates as "limit" the Proclian metaphysical principle- $\pi \dot{\varepsilon} p \alpha \varsigma$.

7 Ioane Petritsi, Commentaria, vol. II, prop. 42, 101, 9-14. 
ciple is not the henad-proper, but the offshoot of the henadic light, its remote illumination or an echo. Otherwise, we shall get a very un-Proclian-perhaps more a Plotinian - doctrine that the human being is a proper divinity deserving to be worshiped. On the contrary, for Petritsi there is not any metaphysical difficulty in saying that each human soul possesses the henad-proper, for as we have seen, for him a henad itself is not a proper deity as to run a risk of making also a human being a deity. Thus, quite strangely, while diminishing the status of henads to that of created metaphysical principles, Petritsi elevates the status of the human soul as the direct possessor of a henad, as capable of participating directly in the $\pi \dot{\varepsilon} p \alpha \varsigma$, or Logos of the Father. Perhaps Petritsi had in mind also the Christian liturgy and the Holy Communion, yet he does not say anything about it explicitly. Rather, the metaphysical communion is taken out of the context of the concrete religious practice and put into a broader picture of philosophical universality. In fact, Christ is called by Petritsi "the Daylight of philosophers"8 and "life-giver of philosophical theories".

\section{The Center of Human Personality}

To return to the initial issue: what are the henads on the anthropological level in Petritsi's Christian universe? No such word is found in Gospels to be sure. Definitely they are the most important aspects of both human existence and cognition. They account for human soul's ascent and return to the One. Moreover, in the revertive eros, the soul first turns in love towards its innate henad, and through its henad to higher henads and ultimately to the One.

"The soul first turns to its essence and observes the multitude of all kinds of beings there, and then it goes deeper and gets rid of the particular ideas." [Afterwards the soul] "first embraces the henad within itself and then through the henad it embraces the ineffable Sun of the henads". ${ }^{10}$

They are referred to alternatively as the "summit of beings" that is to be inebriated by "ambrosia", which could mean that they are divinized by the bestowal of or participation in the Word of God. Petritsi may refer here to the Chaldean Oracles either through Proclus or directly, for they were discussed in the Constantinopolitan philosophical school under Psellos and Italos, with which cir-

$8 \quad$ Ioane Petritsi, Commentaria, vol. II, p. 78.

$9 \quad$ Ioane Petritsi, Epilogue in Commentaria II, p. 220.

10 Ioane Petritsi, Commentaria, vol. II, prop. 15. 49. 23-29. 
cle Petritsi's milieu is commonly associated. The henads are the principles of cognition, the lights within us. With the same function and meaning, Petritsi also speaks about the "logos indwelling in us", or "our innate Hermes". I think, since both the henad of soul and the logos indwelling in our soul hold equally central places for human reality, those two terms can be easily identified: thus, logos within our soul is the henad of soul. This is the principle of human conscience or the "con-" aspect of all "-sciences" the human can possess. What I mean is that this "con-" aspect cannot properly be considered as human and created in a traditional sense inasmuch as anything that is created can be also spoiled or destroyed. A henad or regular logos cannot be destroyed or even spoiled, even though it can be created. It is a principle of infallible knowledge within each of us and as such is a principle of judgment as well: "Our Creator God has implanted in us the dialectic logos, which is within us, called by us the judge indwelling in our heart"." If this principle could be spoiled or damaged then human beings must have still another principle to discern this damage, suffer therefrom and consequently repent, and so ad infinitum. However, even this principle of judgment in us, our inner logos or henad, is not completely selfsufficient, but in need of illumination from the Logos. It represents our bridge to the Logos and the place of our contact with the Logos. All evidence from Petritsi's text indicates that this inner logos or henad cannot be created in time, but it is created in eternity and even pre-eternity (because, in technical Neoplatonic terms, "eternity" applies to the level of intellect—vov̂s—whereas the henads are above intellect and thus pre-eternal). In this sense, we can assume that each human being's henad exists eternally as eternally created by God. But can this henad be called a human person before it is ensouled and embodied? It seems to be like Eriugena's seminal ratio of the being, a yet-non-being in the sense of existing in the hidden folds of deity: in secretissimis intellectualis nat-

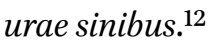

This paradox should be pondered more deeply: it cannot yet be a full-fledged human being, but without it no human being can exist; and it is not yet thinking, but without it no thinking can exist, for the henad or indwelling logos is the principle of determining whether thinking went awry or not, and a "touchstone" for judging the correctness of thinking. Through this doctrine, Petritsi, even though he translates and adheres to Proclus as to the principal authority in the interpretation of Plato, comes closer to Plotinus' tenet that the higher aspect of the human soul never falls and always remains in the intellectual

\footnotetext{
11 Ioane Petritsi, Epilogue, in Commentaria II, p. 207.

12 John Scot Eriugena, De divisione naturae, L. III. 12. (Iohannis Scoti Erigenae De Divisione Naturae Libri Quinque. Monasterii Guestphalorum: Typis et Sumptibus Librariae Aschendorffianae, 1838 , p. 218 .)
} 
realm: similarly, in Petritsi, the presence of henad or inner logos never abandons the human being, as long as it is the principle of his judgment and repentance. From Petritsi's text, one can deduce that this inner henad is individualized in each person; however, those henads possess a primordial fundamental unity, that is why this "inner Hermes" is also called by Petritsi the "common Hermes" for it is similar to all. Thus, philosophers following their inner Hermes form a great society of "brothers and lovers" who love "our Day-light" — Christ. The motion towards universal unity is possible only by embracing one's own individual, unique henad through an inner revelation. In a very significant manner, the initiative in the divine ascent comes from a human agent, for it is a human being who actualizes the inner logos and then comes the divine aid. "Let us with the help of the first Athena invoke the Hermes indwelling in us, so that promythia may come to us through Christ" (ch. 17). In this last quote Petritsi metaphorically calls Christ the "first Athena", for Athena personifies wisdom born out of head of Zeus, as the Logos is born from God the Father. Now, the invocation of the indwelling Hermes, or our innate logos is possible only through the help of the "Athena", that is to say the divine Logos. However, this help of the Logos is still preceded by an initiative of a human agent, as is clear from this quote: "Certainly, if we, in accordance to our natural lot, will contemplate through our reason the deeds of our Creator God and the compositions of [the created] nature, He will give us the kingdom of his Hand, which is the Son, and will communicate to us the Power issuing from Him, which is the Spirit."13

The valorization of the inner cognitive principle, the inner kernel that can come to an immediate contact with the divine Logos is visible also in the way Petritsi consciously flaunts his opposition to the revered tradition. Nobody before Petritsi would speak so irreverently about the saintly theologians who have left translations of the holy texts:

in their vanity willing to shroud themselves with glory, actually [have achieved the contrary and] produced through their irresponsible translations witnesses of their ignorance, rather than of their acumen (...). For instance, it is written [in original Greek] "In the Principle was the Word", 14 but they think it is correct to translate "From the First (or: Firstly) was the Word", unaware [?] that the "first" indicates something presiding among the subsequent things, yet being of the same nature with those things, and

\footnotetext{
13 Ioane Petritsi, Epilogue, in Commentaria II, p. 207.

14 John: 1.1. Petritsi gives here a literal translation of the first verse of the Gospel according to John and criticizes the canonical translation of St. Giorgi Mtatsmindeli, which, according to Petritsi, does not correctly transmit the meaning.
} 
in no wise different by nature from them-for instance, first man among men, or first horse among horses, but not vice-versa, that is to say, first man among horses, as if man were a horse. ${ }^{15}$

For Petritsi even the holy writing itself is to be subjected to the scrutiny of the inner illumination, so that scriptural revelation is in a certain sense subordinated to the inner light, for the inner light has an immediate touch with the Logos, whereas the scripture provides a mediated access to the divine, shrouded in curtains of metaphors that have to be cracked by a philosopher's interpretative efforts.

Most probably, Petritsi was persecuted both in Byzantium and Georgia not only because his specific theological ideas did not match the official dogmas of the Church, but even more importantly, already for his general attitude. He puts the emphasis on the criterion of truth and interpretation on the henadic personal light within each human being which enables a direct access to the divine Logos. Through this statement, in an important way, he undermines the authority of the Church which was supposed to offer the only legitimate access to the Logos-her bridegroom.

\section{3}

\section{Conclusion}

Ioane Petritsi constructs a rigid Christianized doctrine of henads as divine created lights and personifying principles within each human being. They are called "images of God", thus indicating that they represent the most basic kinship of humans with God. It is through them that human beings participate in the divine Logos or $\pi \dot{\varepsilon} p \alpha \varsigma$, or vice versa, it is through them that the Logos touches and divinizes human beings. The henads are created and yet eternal and indestructible, representing the principles of reference of human conscience, eternally or even pre-eternally participating in the Logos and being eternally created by the Logos. This makes Petritsi's anthropology similar to that of Plotinus, in the latter's doctrine of the unfallen aspect of the human soul.

Similarly, in Petritsi, even if soul can fall and man can sin, the presence of the indestructible henadic light that is the very image of God in him/her accounts for the soul's possibility for repentance and reversion towards the higher principles and the One. Moreover, the inner logos, or the inner Hermes- that is to

15 Ioane Petritsi, Epilogue in Commentaria II, p. 219. 
say the indwelling hermeneutical principle in us-provides for Petritsi a direct access for the human soul to metaphysical perfections, without the mediation of any authority, even the authority of the official Church. Thus, by maintaining the personal access to the divinity in a personal mystical ascent, Petritsi, willingly or unwillingly, undermined official religious authority and paved a way to a novel understanding of human selfhood, as more lonely, autonomous and independent, moving toward divinity by his/her own cognitive efforts and mystical experiences. The key reason for the official Church's irritation with Petritsi's personality and works must lie in this fact. The creation of a new dimension of subjectivity with an increased accentuation of human independence had to have its toll.

\section{Bibliography}

\section{Primary Sources}

Gregory Nazianzen, Oratio 38 , in Opera (Patrologia Graeca 36), Paris, 1858.

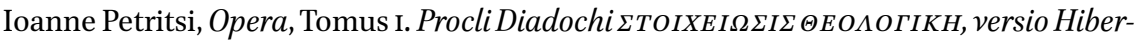
ica. Textum Hibericum edidit commentariisque instruxit S. Kauchtschischvili. Tbilisi, Sumptibus Universitatis Tbilisiensis, 1940 (in Georgian).

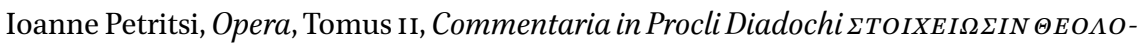
IIKHN. Textum Hibericum ediderunt commentariisque instruxerunt S. Nutsubidse et S. Kauchtschischvili, Tbilisi, Sumptibus Universitatis Tbilisiensis, 1937 (in Georgian).

John Scotus Eriugena, De divisione naturae, Libri Quinque, Monasterii Guestphalorum, Typis et Sumptibus Librariae Aschendorffianae, 1838.

Proclus, The Elements of Theology. A Revised Text with Translation, Introduction and Commentary by E R. Dodds, Oxford, Clarendon Press, $1963^{2}$.

\section{Secondary Sources}

Mchedlidze, M. (2013), "Counsel of Soul: for understanding of criterion in Ioane Petritsi”, in Scientific Papers of the II International Scientific Conference on Language and Culture, Kutaisi, p. 355-362. 